\title{
Synthesis, Evaluation and Molecular Docking Study of Some New 2-[(2,5-Disubstitutedanilino) Phenyl] Acetic Acid Derivatives
}

\author{
Shashidhar Kerur ${ }^{1 *}$, Kallanagouda Alagawadi², Hailiang Zhu³ and Fakkirappa Manvi² \\ ${ }^{1}$ Deparment of Pharmaceutical Chemistry, Karnataka Lingayath Education University College of Pharmacy, Hubli-580031, INDIA \\ ${ }^{2}$ Deparment of Pharmaceutical Chemistry, Karnataka Lingayath Education University College of Pharmacy, Belgaum-580010, INDIA. \\ ${ }^{3}$ State Key Laboratory of Pharmaceutical Biotechnology, Nanjing University, Nanjing-210093, CHINA.
}

\begin{abstract}
In the present study synthesis and antimicrobial activity of some new 2-[(2,5-disubstitutedanilino)phenyl]acetic acid derivatives 5a-f are described. The structures of the newly synthesized compounds were confirmed by FTIR, ${ }^{1} \mathrm{H} N M R,{ }^{13} \mathrm{C}$ NMR, mass and elemental analysis. All compounds were screened for antitubercular and antimicrobial activity. Molecular modeling studies were performed to dock compounds into the ecKAS III binding site, which suggested probable inhibition mechanism. The results revealed that most of the compounds showed high to moderate biological activity against tested microorganisms.
\end{abstract}

Key words: 1,3,4-Thiadiazole, Phenacyl bromide, Molecular Docking, Antitubercular activity, Antimicrobial activity, Mycobacterium tuberculosis.

\section{INTRODUCTION}

Despite the alarming spread of tuberculosis to the public, no sufficiently effective and promising antituberculosis agents have been launched into the pharmaceutical market over the past many years. ${ }^{1}$ Till date Isoniazid (INH), Pyrazinamide, Ethambutol and Rifampicin are considered as promising treatment drugs against the MTB infection. Many published reports ${ }^{2,3}$ on the resistance of these agents against the virulence strains of MTB incite there to develop the antitubcular agents on the priority basis. ${ }^{4}$

During recent years, there has been intense investigations on thiadiazole i.e 2,5-disubstituted -1,3,4-thiadiazole compounds, many of which are known to possess interesting biological properties such as antimicrobial, ${ }^{5}$ anti-inflammatory, ${ }^{6}$ antifungal, ${ }^{7}$ anticonvulsant, ${ }^{8}$ anti-tumor activities. Some members of the 2,5-disubstituted -1,3,4-thiadiazole family displayed good activity against $M$. tuberculosis $\mathrm{H}_{37} \mathrm{Rv}$ strain. ${ }^{10}$

Type II fatty acid synthesis (FAS II) pathway has been recently reported as an attractive targeting for their efficacy against infections caused by mutiresistant Gram-positive bacteria. ${ }^{11}$ There are plenty of fatty acids available to the bacteria inside of the host. ${ }^{12}$ However, FAS II it's proven to be a good target for Gram-negative bacteria. Notably, KAS III, regulates the fatty acid biosynthesis rate via an initiation pathway and its substrate specificity is a key factor in membrane fatty acid composition and this protein represents a promising target for the antimicrobial drugs design. ${ }^{13}$

Inspired from these observations, we planned to synthesize some novel 1,3,4-thiadiazole derivatives (Scheme 1) and get them evaluated for their antitubercular and antimicrobial activity.
Submission Date : 17-12-2015 Revision Date : 04-04-2016 Accepted Date : :24-04-2016

DOI: 10.5530/ijper.50.3.21 Correspondence: Shashidhar S. Kerur, M.Pharm, Ph.D Assistant Professor, Department of Pharmaceutical Chemistry, Karnataka Lingayath Education University College of Pharmacy, Hubli-580031, Karnataka, India.

Tel: +91.836.2373174 Mob:9964317316

Fax: +91.836.2371674 E-mail:shashi_kerur2002@ yahoo.com

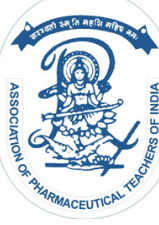

www.ijper.org 


\section{Experimental}

\section{Instrumentation}

All chemicals and reagents used in current study were of analytical grade. The reactions were monitored by thin layer chromatography (TLC) on Merck pre-coated silica GF254 plates. Melting points (uncorrected) were determined on a XT4MP apparatus (Nanjing University, Nanjing, China). The FT-IR spectra were recorded on Thermo Nicolet IR200 FT-IR Spectrometer (Madison WI, USA) by using $\mathrm{KBr}$ pellets. ${ }^{1} \mathrm{H}$ NMR spectra were collected on a Bruker DPX400 or DPX300 spectrometer at room temperature with TMS and solvent signals allotted as internal standards. Chemical shifts are reported in ppm (8). ${ }^{13} \mathrm{C}$ NMR spectra were recorded (in $\mathrm{CDCl}_{3} /$ DMSO- $d_{0}$ ) on a Bruker spectrometer at $300 / 400 \mathrm{MHz}$ using TMS as an internal standard. ESI mass spectra were obtained on a Mariner system 5304 mass spectrometer. Elemental analyses were performed on a CHN-O-Rapid instrument.

\section{Synthesis}

\section{Synthesis of 2-(2,5-diisusbtituted phenylamino)acetic acid (1)}

Equimolar quantities of substituted aniline $(0.1 \mathrm{~N})$, chloroacetic acid and sodium acetate trihydrate were added in presence of ethanol $(50 \mathrm{~mL})$ and were refluxed in an oil bath at $125^{\circ} \mathrm{C}$ for $5 \mathrm{~h}$. The reaction mixture was poured into ice-cold water $(200 \mathrm{~mL})$, the precipitated solid was filtered, washed with cold water, dried and recrystallized using ethanol.

2-(2,5-dichlorophenylamino)acetic acid (1a): Yield: 78\%. M.p.: $123-124^{\circ} \mathrm{C}$. IR (KBr, v, $\left.\mathrm{cm}^{-1}\right)$ : 3375 (NH str.), 3115 $(-\mathrm{OH}), 2953\left(\mathrm{CH}_{2}\right), 1680(\mathrm{C}=\mathrm{O}) .{ }^{1} \mathrm{H} \mathrm{NMR}(400 \mathrm{MHz}$, DMSO-d6, $\delta, \mathrm{ppm}): 11.0$ (s, 1H, OH), 7.77-7.74 (d, 2H, Ar-H), 7.54 (s, 1H, Ar-H), 4.08 (s, 1H, -NH), 4.08 (s, 1H, D $2 \mathrm{O}$ Exchange exp.), 2.82(s, 2H, $\mathrm{CH}_{2}$ ).

2-(2,5-difluorophenylamino)acetic acid (1b): Yield: 66\%. M.p.: $142-144^{\circ} \mathrm{C}$. IR ( $\left.\mathrm{KBr}, \nu, \mathrm{cm}^{-1}\right): 3415$ (NH str.), $3010(\mathrm{OH}), 2874\left(\mathrm{CH}_{2}\right), 1687(\mathrm{C}=\mathrm{O}) \cdot{ }^{1} \mathrm{H}$ NMR (400 MHz, DMSO-d6, $\delta, \mathrm{ppm}): 11.3$ (s, 1H, OH), 7.65 (s, 1H, Ar-H), 7.52 (s, 1H, Ar-H), 7.44 (s, 1H, Ar-H), 4.01 (s, 1H, -NH), 4.01 (s, 1H, D $2 \mathrm{O}$ Exchange exp.), $2.99\left(\mathrm{~s}, 2 \mathrm{H}, \mathrm{CH}_{2}\right)$.

\section{Synthesis of ethyl-2-(2,5-disubstitutedphenylamino) acetate (2)}

1 gram of 2-(2,5-trisusbtituted phenylamino)acetic acid compounds were dissolved in 10-15 mL of ethanol, few drops of conc. sulphuric acid were poured along the sides of the container and refluxed for 8-12 h. During synthesis TLC of the sample were taken for every one hour. TLC solvent ratio: ethanol: chloroform; 7:3.
Ethyl-2-(2,5-dichlorophenylamino) acetate (2a): Yield: 75\%. M.p.: $103-104^{\circ} \mathrm{C}$. IR (KBr, v, cm $\left.{ }^{-1}\right): 3475(\mathrm{NH}$ str.), $2933\left(\mathrm{CH}_{2}\right), 1722(\mathrm{C}=\mathrm{O}) .{ }^{1} \mathrm{H} \mathrm{NMR}(400 \mathrm{MHz}$, DMSO-d6, $\delta, \mathrm{ppm}): 7.70$ (s, 1H, Ar-H), 7.61 (s, 1H, Ar-H), 7.52 (s, 1H, Ar-H), 3.99 (s, 1H, -NH), 3.73 (s, $\left.2 \mathrm{H}, \mathrm{CH}_{2}\right), 2.95$ (s, 2H, $\left.\mathrm{CH}_{2}\right), 1.15\left(\mathrm{~s}, 3 \mathrm{H}, \mathrm{CH}_{3}\right)$.

Ethyl-2-(2,5-difluorophenylamino)acetate (2b): Yield: 61\%. M.p.: $137-139^{\circ} \mathrm{C}$.

IR (KBr, v, cm $\left.{ }^{-1}\right): 3401$ (NH str.), $2988\left(\mathrm{CH}_{2}\right), 1698$ (C=O). ${ }^{1} \mathrm{H}$ NMR (400 MHz, DMSO- $\left.d 6, \delta, \mathrm{ppm}\right): 7.89$ (s, 1H, Ar-H), 7.70(s, 1H, Ar-H), 7.54(s, 1H, Ar-H), 4.02 (s, 1H, -NH), 3.81 (s, 2H, $\left.\mathrm{CH}_{2}\right), 2.85$ (s, 2H, $\left.\mathrm{CH}_{2}\right), 1.34$ $\left(\mathrm{s}, 3 \mathrm{H}, \mathrm{CH}_{3}\right)$.

\section{Synthesis of 2-(substituted phenylamino) acetohydrazide (3)}

To the prepared solution of an ester in absolute ethanol $(50 \mathrm{~mL})$ were added with hydrazine hydrate $99 \%$ in equimolar quantity. The resulting mixture were refluxed on a steam bath for $8 \mathrm{~h}$, the excess ethanol were removed under reduced pressure. The resulting residue was poured into ice cold water $(200 \mathrm{~mL})$. The solid hydrazides thus obtained were recrystallized using ethanol.

2-(2,5-dichlorophenylamino) acetobydrazide (3a): Yield: 70\%. M.p.: $110-112^{\circ} \mathrm{C}$. IR ( $\left.\mathrm{KBr}, \nu, \mathrm{cm}^{-1}\right): 3450\left(\mathrm{NH}_{2}\right)$, 3265 (NH str.), $2953\left(\mathrm{CH}_{2}\right), 1680$ (C=O). ${ }^{1} \mathrm{H}$ NMR (400 MHz, DMSO-d6, $\delta$, ppm): 8.22 (s, 1H, NH $), 7.98$ (s, 1H, NH), 7.70 (s, 1H, Ar-H), 7.64 (s, 1H, Ar-H), 7.54 (s, 1H, Ar-H), 4.08 (s, 1H, NH), 2.98 (s, 2H, $\mathrm{CH}_{2}$ ). 2-(2,5-difluorophenylamino)acetohydrazide (3b): Yield: 58\%. M.p.: $140-142{ }^{\circ} \mathrm{C}$. IR (KBr, v, $\left.\mathrm{cm}^{-1}\right): 3398$ $\left(\mathrm{NH}_{2}\right), 3235$ (NH str.), $2935\left(\mathrm{CH}_{2}\right), 1678$ (C=O). ${ }^{1} \mathrm{H}$ NMR (400 MHz, DMSO-d6, $\delta$, ppm): 8.20 (s, 1H, $\mathrm{NH}_{2}$ ), 7.76 (s, 1H, NH), 7.70 (s, 1H, Ar-H), 7.62 (s, 1H, Ar-H), 7.45 (s, 1H, Ar-H), 4.01 (s, 1H, NH), 2.89 (s, $2 \mathrm{H}, \mathrm{CH}_{2}$ ).

General procedure: Synthesis of 5-((2,5-disubstituted phenylamino)methyl)-1,3,4-thiadiazole-2-thiol (4)

Equimolar quantity of 2-(2,5-disubstituted phenylamino) acetohydrazide, carbon disulphide and few drops of conc. sulphuric acid are added in presence of $15 \mathrm{~mL}$ ethanol and refluxed for $2 \mathrm{~h}$, after reflux cooled to room temperature, which is then poured into crushed ice and neutralized with dilute acetic acid. The resulting solid was filtered, washed with cold water, dried and recrystallized using ethanol.

5-((2,5-dichlorophenylamino)methyl)-1,3,4-thiadiazole-2-thiol (4a): Yield: 68\%. M.p.: $125-126{ }^{\circ} \mathrm{C}$. IR ( $\left.\mathrm{KBr}, \nu, \mathrm{cm}^{-1}\right)$ : 3377 (NH str.), $3117\left(\mathrm{CH}_{2}\right), 784$ (Cl str.). ${ }^{1} \mathrm{H}$ NMR (400 $\mathrm{MHz}, \mathrm{DMSO}-d 6, \delta, \mathrm{ppm}): 12.87$ (s, 1H, -SH), 7.86 (s, 1H, Ar-H), 7.52 (s, 1H, Ar-H), 4.01 (s, 1H, NH), 2.88 $\left(\mathrm{s}, 2 \mathrm{H}, \mathrm{CH}_{2}\right)$. 
5-((2,5-difluorophenylamino)methyl)-1,3,4-thiadiazole-2-thiol (4b): Yield: $57 \%$. M.p.: $191-193^{\circ} \mathrm{C}$. IR $\left(\mathrm{KBr}, \nu, \mathrm{cm}^{-1}\right)$ : 3437 (NH str.), $3271\left(\mathrm{CH}_{2}\right), 760$ (Cl str.). ${ }^{1} \mathrm{H}$ NMR (400 $\mathrm{MHz}, \mathrm{DMSO}-d 6, \delta, \mathrm{ppm}): 12.78$ (s, $1 \mathrm{H},-\mathrm{SH}), 7.87$ (s, 1H, Ar-H), 7.67-7.64 (d, 2H, Ar-H), 4.07 (s, 1H, NH), $2.65\left(\mathrm{~s}, 2 \mathrm{H}, \mathrm{CH}_{2}\right)$.

\section{Preparation of derivatives of 1-(2,5-disubstitutedphenyl)- 2-(5-((substitutedphenylamino)methyl)-1,3,4-thiadiazol- 2-ylthio)ethanone}

Equimolar quantity of 5-((2,5-disubstitutedphenylamino) methyl)-1,3,4-thiadiazole-2-thiol compounds (0.005 mole) were treated with $p$-substituted phenacyl bromide $(0.005$ mole) in the presence of ethanol $(50 \mathrm{~mL})$. Refluxed for $1 \mathrm{~h}$ on oil bath to give the different derivatives of 1,3,4-thiadiazole at the $C_{2}$ positions respectively.

2-(5-((2,5-dichlorophenylamino)methyl)-1,3,4-thiadiazol2-ylthio)-1-phenyl ethanone (5a):

Yield: $62 \%$. M.p.: $232-234^{\circ} \mathrm{C}$. $\mathrm{IR}\left(\mathrm{KBr}, \nu, \mathrm{cm}^{-1}\right): 3375(\mathrm{NH}$ str.), $3046\left(\mathrm{CH}_{2}\right), 1722$ (C=O), 717 (Cl str.). ${ }^{1} \mathrm{H}$ NMR (400 MHz, DMSO-d6, $\delta$, ppm): 8.10 (s, $1 \mathrm{H}, \mathrm{Ar}-\mathrm{H}), 7.92$ (s, 1H, Ar-H), 7.64-7.62 (d, J = 8.2 Hz, 2H, Ar-H), 7.337.31 (d, $J=7.6 \mathrm{~Hz}, 2 \mathrm{H}, \mathrm{Ar}-\mathrm{H}), 6.93(\mathrm{~s}, 1 \mathrm{H}, \mathrm{Ar}-\mathrm{H}), 4.03$ (s, 1H, NH), 3.87 (s, 2H, -S-CH $-\mathrm{CO}), 2.50$ (s, 2H, $\mathrm{CH}_{2}$ ). ${ }^{13} \mathrm{C}$ NMR (DMSO- $\left.d_{6}, \delta, \mathrm{ppm}\right): 193.52(\mathrm{C}=\mathrm{O}), 160.07$ (C2-triazolic ring), 157.06 (C5-triazolic ring), 142.11, 140.03, 131.32, 130.15, 124.99, 121.50, 119.61, 112.97 (Aromatic ring), $49.23\left(\mathrm{CH}_{2}\right), 39.02\left(-\mathrm{S}-\mathrm{CH}_{2}-\mathrm{CO}\right)$.

MS (ESI-QqTOF, $m / 2$ ): $409.09[\mathrm{M}+\mathrm{H}]^{+}$. Anal. calcd. for $\mathrm{C}_{17} \mathrm{H}_{13} \mathrm{Cl}_{2} \mathrm{~N}_{3} \mathrm{OS}_{2}$ : C, 49.71; H, 3.05; N, 10.31. Found: C, 49.68; H, 3.03; N, 10.30\%.

2-(5-((2,5-difluorophenylamino)methyl)-1,3,4-thiadiazol2-ylthio)-1-phenylethanone (5b):

Yield: $51 \%$.

M.p.: $245-247^{\circ} \mathrm{C}$. IR(KBr, $\left.\nu, \mathrm{cm}^{-1}\right): 3348$ (NH str.), 3037 $\left(\mathrm{CH}_{2}\right), 1738$ (C=O), 714 (F str.).

${ }^{1} \mathrm{H}$ NMR (400 MHz, DMSO-d6, $\left.\delta, \mathrm{ppm}\right): 7.91$ (s, 1H, Ar-H), 7.82 (s, 1H, Ar-H), 7.57-7.54 (d, $J=8.6 \mathrm{~Hz}$, $2 \mathrm{H}, \operatorname{Ar}-\mathrm{H}), 7.24-7.21$ (d, $J=8.2 \mathrm{~Hz}, 2 \mathrm{H}, \mathrm{Ar}-\mathrm{H}), 7.02$ (s, 1H, Ar-H), 4.06 (s, 1H, NH), 3.54 (s, 2H, -S-CH ${ }_{2}^{-}$ $\mathrm{CO}$ ), 2.07 (s, 2H, $\left.\mathrm{CH}_{2}\right) \cdot{ }^{13} \mathrm{C}$ NMR (DMSO- $d_{6}$, $\delta$, ppm): 187.33(C=O), 158.27 (C2-triazolic ring), 150.12 (C5-triazolic ring), 141.17, 140.09, 134.76, 130.57, 127.19, 120.77, 118.78, 112.07 (Aromatic ring), $50.21\left(\mathrm{CH}_{2}\right)$, 38.22 (-S-CH$-\mathrm{CO})$.

MS (ESI-QqTOF, $m / 2$ ): $377.41[\mathrm{M}+\mathrm{H}]^{+}$. Anal. calcd. for $\mathrm{C}_{17} \mathrm{H}_{13} \mathrm{~F}_{2} \mathrm{~N}_{3} \mathrm{OS}_{2}$ : C, 54.10; H, 3.45; N,11.12. Found: C, 54.08; H, 3.42; N, 11.08\%.

2-(5-((2,5-dichlorophenylamino)methyl)-1,3,4-thiadiazol2-ylthio)-1-(4-chloro phenyl)ethanone (5c):

Yield: $45 \%$. M.p.: $240-241{ }^{\circ} \mathrm{C} . \mathrm{IR}\left(\mathrm{KBr}, \nu, \mathrm{cm}^{-1}\right): 3375$ (NH str.), $3048\left(\mathrm{CH}_{2}\right), 1723$ (C=O), 725 (Cl str.). ${ }^{1} \mathrm{H}$
NMR (400 MHz, DMSO-d6, $\delta, \mathrm{ppm}): 8.61$ (s, 1H, Ar-H), 8.10 (s, 1H, Ar-H), 7.77-7.75 (d, J = 8.0 Hz, $2 \mathrm{H}, \mathrm{Ar}-\mathrm{H}$ ), 7.25-7.24 (d, J = 7.6 Hz, 2H, Ar-H), 3.99 (s, $1 \mathrm{H}, \mathrm{NH}), 3.01$ (s, 2H, -S-CH$-\mathrm{CO}$ ), 2.62 (s, 2H, $\mathrm{CH}_{2}$ ). ${ }^{13} \mathrm{C}$ NMR (DMSO- $\left.d_{6}, \delta, \mathrm{ppm}\right): 194.78(\mathrm{C}=\mathrm{O}), 164.96$ (C2-triazolic ring), 135.75 (C5-triazolic ring), 133.88, $131.63,130.57,130.01,129.03,127.16,114.72,110.17$ (Aromatic ring), $50.89\left(\mathrm{CH}_{2}\right), 38.87$ (-S-CH $\left.\mathrm{CH}_{2}-\mathrm{CO}\right)$. MS (ESI-QqTOF, $m / z$ ): $444.81[\mathrm{M}+\mathrm{H}]^{+}$. Anal. calcd. for $\mathrm{C}_{17} \mathrm{H}_{12} \mathrm{Cl}_{3} \mathrm{~N}_{3} \mathrm{OS}_{2}: \mathrm{C}, 45.91 ; \mathrm{H}, 2.71 ; \mathrm{N}, 9.47$. Found: C, 45.90; H, 2.70; N, 9.45\%.

2-(5-((2,5-difluorophenylamino)methyl)-1,3,4-thiadiazol-2-ylthio)-1-(4-chloro phenyl)ethanone (5d): Yield: 54\%. M.p.: $215-216{ }^{\circ} \mathrm{C} . \operatorname{IR}\left(\mathrm{KBr}, \nu, \mathrm{cm}^{-1}\right)$ : 3441 (NH str.), $3377\left(\mathrm{CH}_{2}\right), 1715$ (C=O), 730 (F str.). ${ }^{1} \mathrm{H}$ NMR (400 $\mathrm{MHz}, \mathrm{DMSO}-d 6, \delta, \mathrm{ppm}): 7.83$ (s, $1 \mathrm{H}, \mathrm{Ar}-\mathrm{H}), 7.67$ (s, 1H, Ar-H), 7.12-7.09 (d, J = 7.8 Hz, 2H, Ar-H), 6.98-6.96 (d, J = 7.2 Hz, 2H, Ar-H), 4.01 (s, 1H, NH), 3.85 (s, $\left.2 \mathrm{H},-\mathrm{S}-\mathrm{CH}_{2}-\mathrm{CO}\right), 2.46\left(\mathrm{~s}, 2 \mathrm{H}, \mathrm{CH}_{2}\right) \cdot{ }^{13} \mathrm{C} \mathrm{NMR}$ (DMSO- $\left.d_{6}, \delta, \mathrm{ppm}\right): 192.71(\mathrm{C}=\mathrm{O}), 167.69$ (C2-triazolic ring), 136.76(C5- triazolic ring), 131.18, 130.63,130.07, 129.88, 129.03, 126.16; 115.72, 111.17(aromatic ring), $49.89\left(\mathrm{CH}_{2}\right), 39.97\left(-\mathrm{S}-\mathrm{CH}_{2}-\mathrm{CO}\right)$.

MS (ESI-QqTOF, $m / z)$ ) $411.1[\mathrm{M}+\mathrm{H}]^{+}$. Anal. calcd. for $\mathrm{C}_{17} \mathrm{H}_{12} \mathrm{ClF}_{2} \mathrm{~N}_{3} \mathrm{OS}_{2}$ : C, 49.56; H, 2.93; N, 9.23. Found: C, 49.54; H, 2.92; N, 9.24\%.

2-(5-((2,5-dichlorophenylamino)methyl)-1,3,4-thiadiazol-2-ylthio)-1-(4-fluoro phenyl)ethanone (5e): Yield: 58\%. M.p.: 212-215 ${ }^{\circ} \mathrm{C} . \mathrm{IR}\left(\mathrm{KBr}, \nu, \mathrm{cm}^{-1}\right): 3375$ (NH str.), 3046 $\left(\mathrm{CH}_{2}\right), 1722(\mathrm{C}=\mathrm{O}), 717$ (Cl str.). ${ }^{1} \mathrm{H}$ NMR $(400 \mathrm{MHz}$, DMSO-d6, $\delta, \mathrm{ppm}): 8.12$ (s, $1 \mathrm{H}, \mathrm{Ar}-\mathrm{H}), 7.92$ (s, $1 \mathrm{H}$, Ar-H), 7.35-7.32 (d, J = 8.6 Hz, 2H, Ar-H), 7.05-7.02 (d, $J=7.4 \mathrm{~Hz}, 2 \mathrm{H}, \mathrm{Ar}-\mathrm{H}), 4.07$ (s, $1 \mathrm{H}, \mathrm{NH}), 3.81$ (s, 2H, -S-CH$-\mathrm{CO}$ ), 2.42 (s, $\left.2 \mathrm{H}, \mathrm{CH}_{2}\right) \cdot{ }^{13} \mathrm{C}$ NMR (DMSO- $d_{6}$, $\delta$, ppm): 193.20 (C=O), 162.50 (C2-triazolic ring), 152.72 (C5-triazolic ring), 141.30, 139.89, 134.38, 132.37, 130.06, 129.09, 127.88, 127.33, 126.61 (Aromatic ring), $49.27\left(\mathrm{CH}_{2}\right), 39.63$ (-S-CH$\left.-\mathrm{CO}\right)$. MS (ESI-QqTOF, $\mathrm{m} / \mathrm{z}): 428.32[\mathrm{M}+\mathrm{H}]^{+}$.

Anal. calcd. for $\mathrm{C}_{17} \mathrm{H}_{12} \mathrm{Cl}_{3} \mathrm{FN}_{3} \mathrm{OS}_{2}$ : C, 47.67; H, 2.80; N, 16.55. Found: C, 47.66; H, 2.79; N, 16.54\%.

2-(5-((2,5-difluorophenylamino)methyl)-1,3,4-thiadiazol-2-ylthio)-1-(4-fluoro phenyl)ethanone (5f): Yield: 54\%. M.p.: 240-241 ${ }^{\circ} \mathrm{C} . \mathrm{IR}\left(\mathrm{KBr}, v, \mathrm{~cm}^{-1}\right): 3348$ (NH str.), 3037 $\left(\mathrm{CH}_{2}\right), 1738$ (C=O), 717 (F str.). ${ }^{1} \mathrm{H}$ NMR $(400 \mathrm{MHz}$, DMSO-d6, $\delta, \mathrm{ppm}): 8.12$ (s, 1H, Ar-H), 7.83 (s, 1H, Ar-H), $7.52-7.50$ (d, J = 8.6 Hz, 2H, Ar-H), 6.60$6.58(\mathrm{~d}, J=6.6 . \mathrm{Hz}, 2 \mathrm{H}, \operatorname{Ar}-\mathrm{H}), 4.09$ (s, 1H, NH), 3.83 (s, 2H, -S-CH $-\mathrm{CO}), 2.52\left(\mathrm{~s}, 2 \mathrm{H}, \mathrm{CH}_{2}\right) \cdot{ }^{13} \mathrm{C} \mathrm{NMR}$ (DMSO- $\left.d_{6}, \delta, \mathrm{ppm}\right):$ 193.1(C=O), 162.77(C2-triazolic ring), 152.10(C5-triazolic ring), 142.90, 140.71, 133.68, 130.91, 130.20, 127.60, 123.9, 123.7, 115.18 (Aromatic 
ring), $49.21\left(\mathrm{CH}_{2}\right), 39.17$ (-S-CH$\left.{ }_{2}-\mathrm{CO}\right)$. MS (ESI-QqTOF, $m / g): 495.41[\mathrm{M}+\mathrm{H}]^{+}$.

Anal. calcd. for $\mathrm{C}_{17} \mathrm{H}_{12} \mathrm{~F}_{3} \mathrm{~N}_{3} \mathrm{OS}_{2}: \mathrm{C}, 51.64 ; \mathrm{H}, 3.06 ; \mathrm{N}$, 10.63. Found: C, 51.62; H, 3.06; N, 10.62\%.

\section{Biological evaluation}

\section{In vitro evaluation of antimicrobial activity}

The MIC determination of the tested compounds were carried out in comparison with Norfloxacin for their antibacterial activity against two micro-organisms viz. E. coli (NCTC 10418) and S. aureus (NCTC 6571) by Cup-plate agar diffusion method using Mueller-Hinton agar. The MIC determinations of the tested compounds were carried out by comparison with Griseofulvin for their antifungal activity against $C$. albicans (ATCC 10231) and A. niger (ATCC 16404) by Cup-plate agar diffusion method using Sabouraud-Dextrose agar. Drugs $(10 \mathrm{mg})$ were dissolved in Dimethylsulfoxide (DMSO, $1 \mathrm{~mL}$ ). The tubes were inoculated with $10^{5} \mathrm{cfu} / \mathrm{mL}$ (colony forming unit $/ \mathrm{mL}$ ) and incubated at $37^{\circ} \mathrm{C}$ for $18 \mathrm{~h}$. The MIC was the lowest concentration of the tested compound that yields no visible growth on the plate. To ensure that the solvent had no effect on the bacterial growth, a control was performed with DMSO at the same dilutions as used in the experiments and it was observed that DMSO with $2 \%$ had no effect on the microorganisms in the concentrations studied.

\section{In vitro evaluation of antitubercular activity}

The antimycobacterial activity of compounds were assessed against $M$. tuberculosis using microplate Alamar Blue assay (MABA). The 96 wells plate received $100 \mu \mathrm{L}$ of the Middlebrook $7 \mathrm{H} 9$ broth and serial dilution of compounds were made directly on plate. The final drug concentrations tested were 100 to $0.2 \mu \mathrm{g} / \mathrm{mL}$ and incubated at $37^{\circ} \mathrm{C}$ for five days. After this $25 \mu \mathrm{L}$ of freshly prepared 1:1 mixture of Almar Blue reagent and 10\% tween 80 was added to the plate and incubated for 24 hrs. A blue color in the well was interpreted as no bacterial growth, and pink color was scored as growth. The MIC was defined as lowest drug concentration which prevented the color change from blue to pink. Against the standard drug Isoniazid.

\section{Experimental protocol of molecular docking studies}

The synthesized molecules were subjected for molecular docking by calculating the minimum energy to inhibit the target protein involved in the catalysis of complex reaction. The ligands were drawn in Chemdraw Ultra 11.0 assigned with proper 2D orientation (Chemoffice package) and the structure of each ligand was analysed by using Chem-3D Ultra 11.0 (Chem Office package) and was checked for the connection error in bond order. ADMET property was achieved through Pre ADMET server a web-based application for predicting ADMET data and building drug-like library using in silico method. Energy of the molecules was minimized by using MOPAC with 100 interactions and minimum RMS. Then the file was opened in Accelrys, DS visualizer 2.0 [Accelrys Inc., San Diego, CA (2007)] and to determine their binding orientations, molecular modeling, and evaluation of the hydrogen bonds. Active pockets were identified and ligplot of PDBSum provided in the External links of PDB for the proteins was downloaded from PDB. CASTp (Computed Atlas of Surface Topography of proteins) server was used to crosscheck the active pockets on target protein molecules. Autodock V4.0 was used to perform molecular docking. The docking results for ligand molecules against ecKAS III synthase [PDB CODE: 1HNJ], showed minimum docking energy, binding energy, number of binding sites with 0.0 RMS as documented in Table 2.

\section{RESULT AND DISCUSSION}

The synthetic route of the compounds (5a- $\mathrm{f})$ is outlined in Scheme 1. The 2-(substituted phenylamino)acetic acid (1) was prepared by the reaction of equimolar quantities of chloroacetic acid and substituted aniline according to the established procedures. ${ }^{13}$ Ethyl-2(substitutedphenylamino)acetate (2) was obtained by refluxing 2-(susbtituted phenylamino)acetic acid (1) and Concentrated sulphuric acid in presence of dry ethanol to form esters. ${ }^{14} 2$-(substituted phenylamino)acetohydrazide (3) was prepared by hydrozinolysis of the esters. Synthesis of 5-((substitutedphenylamino)methyl)-1,3,4thiadiazole-2-thiol (4) was achieved by adopting a simple one pot procedure that involves reacting hydazides with carbon disulfide and conc. sulphuric acid. ${ }^{15}$ The alkylation of 1,3,4-thiadiazoles (4) with substituted phenycyl bromide, in presence of dimethyl sulfoxide afford a new series of 1-(2,5-disubstitutedphenyl)-2(5-((substitutedphenylamino)methyl)-1,3,4-thiadiazol2-ylthio)ethanone (5a-f). ${ }^{16}$

The formation of 2-substituted phenylamino acetic acid (1) was confirmed by IR spectra, which showed the presence of amine(-NH) bands at around 3415 to 3375 and ${ }^{1} \mathrm{H}$ NMR $\mathrm{D}_{2} \mathrm{O}$ exchange experiment around $\delta 4.08$ ppm. Ethyl-2-(substituted phenylamino) acetate (2) showed around 1722 to $1698(\mathrm{C}=\mathrm{O})$. 2-(Substituted phenylamino) acetohydrazide (3) was confirmed by 3450 to $3398\left(\mathrm{NH}_{2}\right)$ and the signal was observed around $\delta 8.22$ in the ${ }^{1} \mathrm{H}$ NMR. A new signal for $\mathrm{SH}$ group was appeared as singlet at $\delta 12.87-12.78 \mathrm{ppm}$. In the ${ }^{1} \mathrm{H}$ NMR spectra of 1-(2,5-disubstitutedphenyl)- 


\begin{tabular}{|c|c|c|c|c|c|}
\multicolumn{6}{|c|}{ Table 1: Antimicrobial and anti-tubercular screening results of compound } \\
(MIC values $\mu \mathrm{g} / \mathrm{mL}$ )
\end{tabular}

NT: not tested.

\begin{tabular}{|c|c|c|c|}
\hline \multicolumn{4}{|c|}{ Table 2: Molecular docking simulation results with ecKAS III } \\
synthase \\
\hline Molecule No & Binding energy & Docking energy & No of binding sites \\
\hline $5 a$ & -5.49 & -5.70 & 04 \\
\hline $5 b$ & -6.79 & -6.92 & 03 \\
\hline $5 c$ & -5.79 & -5.92 & 02 \\
\hline $5 d$ & -6.53 & -6.81 & 04 \\
\hline $5 e$ & -6.99 & -7.22 & 03 \\
\hline $5 f$ & -5.19 & -5.24 & 02 \\
\hline
\end{tabular}
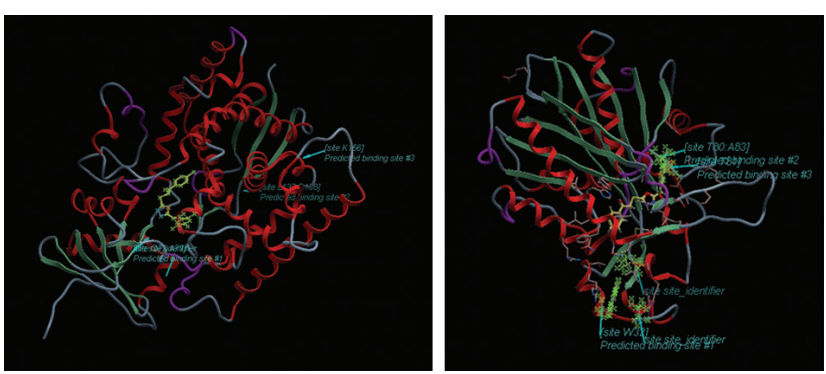

Figure 1: Compound $1 \mathrm{~b}$ is bound into ecKAS III receptor site via hydrophobic interactions and hydrophilic binding by hydrogen bond between its $\mathrm{O}$ and H-S of Asn 274 (S-H...02: 2.03 $\AA$ Å, $\left.137.8^{\circ}\right)$ and $\mathrm{H}-\mathrm{S}$ of Ala 109 (S-H...02: $2.08 \AA$, 148.7 ${ }^{\circ}$ ) and extending into the mouth of the substrate tunnel $(2 \mathrm{~d}(\mathrm{ii}))$.
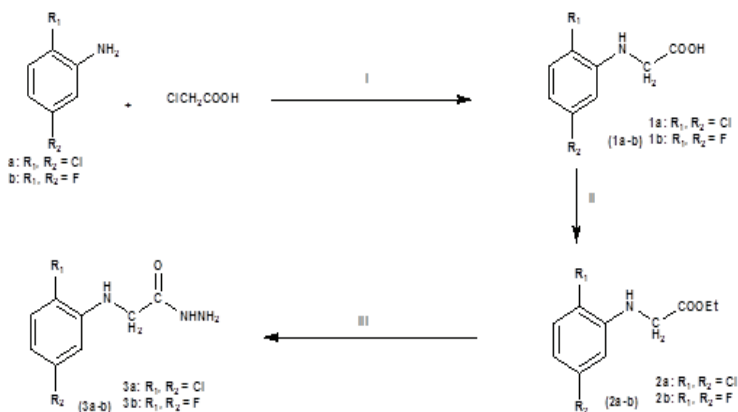

|<smiles>CCCCCCNc1nnc(CNc2cc(C)ccc2C)s1</smiles>

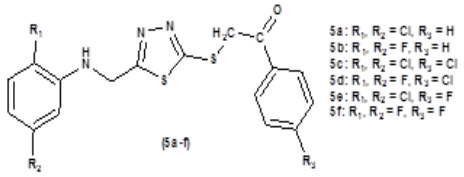

Scheme 1: Reagents used: i) Ethanol, $5 \mathrm{~h}, 125^{\circ} \mathrm{C}$; ii) Conc. sulphuric acid, dry ethanol, $8 \mathrm{~h}, 90^{\circ} \mathrm{C}$; iii) Hydrazine hydrate, ethanol, $8 \mathrm{~h}, 85^{\circ} \mathrm{C}$; iv) Carbon disulphide, conc. sulphuric acid, $2 \mathrm{~h}, 85^{\circ} \mathrm{C}$; v) p-substituted phenacyl bromide, $1 \mathrm{~h}, 80^{\circ} \mathrm{C}$. 
2-(5-((substitutedphenylamino)methyl)-1,3,4-thiadiazolylthio)ethanone (5a-f) were confirmed by absence of $\mathrm{SH}$ peak, while the signal of methylene proton (2.62$2.07 \mathrm{ppm}$ ) from compounds were appeared. The above facts were further evidenced by ${ }^{13} \mathrm{C}$ NMR data which displayed $\mathrm{C}=\mathrm{O}$ signals at $\delta 194.78-\delta 187.77 \mathrm{ppm}$, the heterocyclic carbons resonated at $\delta 167.69$ to $\delta 110.17$ ppm and $\mathrm{CH}_{2}$ group resonated at 39.97 to $38.22 \mathrm{ppm}$ respectively. The mass spectrum of compounds showed molecular ion peaks at $m / z 475.1$ to 395.0 corresponding to molecular formula and elemental analysis of these compounds further confirmed the assigned structures.

\section{Biological evaluation}

\section{In vitro antimicrobial studies}

The investigation of antimicrobial screening revealed that some of compounds showed moderate to good bacterial and fungal inhibition. Particularly compounds $5 \mathrm{a}$ and $5 \mathrm{~d}$ showed good activity against E. Coli and S. aureus with MIC values between 8 to $16 \mu \mathrm{g} / \mathrm{mL}$. All the remaining compounds $5 \mathrm{~b}, 5 \mathrm{e}$ and $5 \mathrm{f}$ showed moderate activity, where as $5 c$ shown less activity. The investigation of antifungal screening revealed that compounds $5 \mathrm{a}$ and $5 \mathrm{e}$ showed good activity against $A$. niger and $C$. albicans with MIC values between 8 to $16 \mu \mathrm{g} / \mathrm{mL}$. All the remaining compounds $5 \mathrm{~b}, 5 \mathrm{c}$ and $5 \mathrm{f}$ showed moderate activity, where as $5 \mathrm{~d}$ shown less activity. The MIC values of tested compounds are given in Table $1 .{ }^{17}$

\section{In vitro antitubercular studies}

The antitubercular screening revealed that some of the tested compounds showed moderate to good inhibition against standard drug Isoniazid. Particularly compounds $5 \mathrm{a}$ and $5 \mathrm{~d}$, have shown good activity with MIC values between 0.4 to $1.6 \mu \mathrm{g} / \mathrm{mL}$. All the remaining compounds $5 \mathrm{~b}, 5 \mathrm{e}$ and $5 \mathrm{f}$ showed moderate activity, where as $5 \mathrm{c}$ has shown less activity. ${ }^{18}$

\section{Molecular docking studies}

With in vitro antimicrobial results in hand, it is thought worth-while to do in silico studies to support the in vitro activity. Automated docking was used to determine the orientation of inhibitors bound in the active site of ecKAS III synthase. A Lamarckian genetic algorithm method was employed. The docking of ligand molecules with ecKAS III synthase reveals that all the inhibitor compounds are exhibited the bonding with one or other amino acids in the active pockets which is showed in Figure 1. The protein structure file (PDB ID: 1hnj) taken from PDB (www.rcsb.org/pdb) was edited by removing the hetero atoms, adding C-terminal oxygen. Figure 1 also shows the in silico active pocket prediction of amino acids of protein ecKAS III synthase involved in binding with the ligands obtained from PDB sum. Theoretically all the molecules showed very good binding energy and docking energy ranging from -5.19 to $-6.99 \mathrm{~kJ} / \mathrm{mol}$ and -5.24 to $-7.22 \mathrm{~kJ} / \mathrm{mol}$, respectively. Among the 6 molecules, docking of ecKAS III synthase with $5 \mathrm{~b}$ and $5 \mathrm{f}$ revealed that its docking energy and binding energy were $-6.79,-6.92,-6.99$, and $-7.22 \mathrm{~kJ} / \mathrm{mol}$, respectively, and it may be considered as good inhibitor of ecKAS III synthase. In in-vitro also $5 \mathrm{~b}$ and $5 \mathrm{f}$ has emerged as active against all tested microorganisms, so it can be predicted as the activity may be due to inhibition of enzyme ecKAS III synthase. ${ }^{19,20}$

\section{CONCLUSION}

We have synthesized series of novel S-substituted phenacyl-1,3,4-thiadiazole-thiol derivatives (5a-f). The results of antimicrobial screening revealed the discovery of new compounds as one of the promising agents. This observation may promote a further development of this group of 1,3,4-thiadiazole-thiol may lead to compounds with better pharmacological profile than standard antimicrobial drugs. Molecular docking studies also revealed that $\mathbf{5} \mathbf{b}$ and $\mathbf{5} \mathbf{f}$ has minimum binding and docking energy and may be considered as a good inhibitor of ecKAS III. Hence this study has widened the scope of developing these derivatives as promising antitubercular, antibacterial and antifungal agents.

\section{ACKNOWLEDGEMENTS}

Author expresses his deepest thank to Dr. Basangouda Patil, Principal, Karnataka Lingayath Education University College of Pharmacy, Hubli. For his timely help.

\section{CONFLICT OF INTEREST}

Authors declare that there is no conflict of interest for this article.

\section{ABBREVIATION USED}

MTB: Mycobacterium Tuberculosis; FAS: Fatty Acid Synthesis; KAS: Beta-ketoacyl-ACP synthase; PDB: Protein Data Bank; MIC: Minimum Inhibitory Concentration.

\section{REFERENCES}

1. Soumya S. Clinical Presentation and Treatment of HIV-TB. Indian J Tub. 2002;49:10-11.

2. Jolly VS, Pathak M. Synthesis and biological activities of some new aryl azopyrazoles, Synthesis and biological activities of some new aryl azopyrazoles. Indian J Chem. 1993;32B:502-5. 
3. Christensen CE, Kragelund BB, Von PWK, Henriksen A. Structure of the human beta-ketoacyl [ACP] synthase from the mitochondrial type II fatty acid synthase. Protein Sci. 2007;16:261-7. http://dx.doi.org/10.1110/ ps.062473707 ; PMid:17242430:PMCid:PMC2203288.

4. De Jong BC, Israelski DM, Corbett EL, Small PM. Clinical management of tuberculosis in the context of HIV infection. Annu Rev Med. 2004;55:280-304. http://dx.doi.org/10.1146/annurev.med.55.091902.103753 ; PMid:14746522.

5. Kemal S, Yasemin U, Mustafa ER. Synthesis of 2-acylamino-2-aroylamino and ethoxy carbonylimino-1,3,4-thiadiazoles as antitumor agents. Turk J Chem. 2007;31:125-34.

6. Foroumadi AS, Sharifzades Z, Hemmateenejod B, Moshafi MH. Synthesis, antituberculosis activity and QSAR study of some novel 2-(nitroaryl)-5 (nitrobenzylsulfoxy) and sulfonyl)-1,3,4-thiadiazole derivatives. DARU. 2007;15:218-26.

7. Mogilaiah K, Chowdary DS. Synthesis and antibacterial activity of pyrazole and 1,3,4-oxadiazole derivatives of 2-phenyl-1,8-naphthyridine. Indian $\mathrm{J}$ Chem. 2001;40B:43-8. http://dx.doi.org/10.1002/chin.200123110.

8. Mohamed A and Shikha K, Synthesis and anti-inflammatory, analgesic, ulcerogenic and lipid peroxidation activities of some new 2-[(2,6-dicloroanilino) phenyl]acetic acid derivatives. Eur J Med Chem. 2004;39:535-45. http:// dx.doi.org/10.1016/j.ejmech.2004.02.008; PMid:15183912.

9. Fang L, Xiao-Qiong L, Pinaki S, Song Y. Synthesis and antifungal activity of novel sulfoxide derivatives containing trimethoxyphenyl substituted 1,3,4-thiadiazole and 1,3,4-oxadiazole moiety. Bioorg Med Chem. 2008;16:3632-3640. http://dx.doi.org/10.1016/j.bmc.2008.02.006 ; PMid:18329885.

10. Khalid MK, Naheed F, Maimona R, Saima J, Shahnaz PM. 1,3,4-Oxadiazole$2(3 \mathrm{H})$ thione and its analogues: A new class of non-competitive nucleotide pyrophosphatases/phosphodiesterases inhibitors. Bioorg Med Chem. 2009;12:481-6.

11. Padmavati V, Sudhakar RG, Padmaja A. Synthesis, antimicrobial and cytotoxic activities of 1,3,4-oxadiazoles, 1,3,4-thiadiazoles and 1,2,4-triazoles. Eur J Med Chem. 2009;44:2106-2112. http://dx.doi. org/10.1016/j.ejmech.2008.10.012; PMid:19036476
12. Dalip Kumar, 10. Khalid MK, Naheed F, Maimona R, Saima J, Shahnaz PM. 1,3,4-oxadiazole-2(3H)thione and its analogues: A new class of noncompetitive nucleotid pyrophosphatases/phosphodiesterases inhibitors. Bioorg Med Chem. 2009;12:481-6.

13. Talwar MB, Desai SR, Somannavar YS, Marihal SC, Bennur SC. Synthesis and antimicrobial activity of 2(phenyl thiosulfonyl) methyl-5-substituted-1,3,4thiadiazole. Indian J Hetero Chem. 1996;5:215-8.

14. Bhaskar D, Rajesh HD. An efficient general method for esterification of aromatic carboxylic acids. Tetra lett. 1996;37(35):6375-78. http://dx.doi. org/10.1016/0040-4039(96)01351-2.

15. Joshi SD, Vagdevi HM, Vaidya VP, Gadaginamath GS. Synthesis of new 4-pyrrol-1-yl benzoic acid hydrazide analogs and some derived oxadiazole, triazole and pyrrole ring systems: A novel class of potential antibacterial and antitubercular agents. Eur J Med Chem. 2008;43:1989-96. http://dx.doi. org/10.1016/j.ejmech.2007.11.016; PMid:18207286

16. Stefania-Felicia B, Gabriela LA, loanna S, Constantin D, Ana IT, Gabriela B. Synthesis, characterization and evaluation of antibacterial activity of some thiazolo[3,2 b][1,2,4]triazole incorporating diphenylsulfone moieties. Eur J Med Chem. 2009;44:4752-57. http://dx.doi.org/10.1016/j. ejmech.2009.06.021; PMid:19616347

17. Pattan SR, Reddy VVK, Manvi FV, Desai BG, Bhat AR. Synthesis of N-3(4-(4-Chlorophenylthiazole-2-yl)-(2-(amino)methyl)-quinazoline-4(3H)one and their derivatives for antitubercular activity. Indian $\mathrm{J}$ Hetero Chem. 2006;45(B):1778-81.

18. Bauer RW, Kirby MDK, Sherris JC, Turck M. Antibiotic susceptibility testing by standard single disc diffusion method. American J Clinical Pathology. 1966;45:493-6. PMid:5325707

19. Paul MK, Mukhopadhyay AK. Tyrosine kinase - Role and significance in cancer. Int J Med Sci. 2004;1:101-6. http://dx.doi.org/10.7150/ijms.1.101 ; PMid:15912202 PMCid:PMC1074718

20. Morris GM, Goodsell DS, Halliday RS, Huey R, Hart WE, Belew RK, Olson AJ. Automated docking using a lamarckian genetic algorithm and and empirical binding free energy function. J Comput Chem. 1998;19:1639-42. http://dx.doi.org/10.1002/(SICI)1096-987X(19981115)19:14<1639::AIDJCC10>3.0.CO;2-B.

\section{SUMMARY}

- MTB has in the emergence of drug-resistant tuberculosis.

- There has been intense investigations on thiadiazole i.e 2,5-disubsti $\neg$ tuted $-1,3,4$-thiadiazole compounds, which are known to possess interesting biological properties.

- The results of antimicrobial screening revealed the discovery of new compounds as one of the promising agents.

- Molecular Docking study also reveals promising results for synthesized compounds.

- This study has widened the scope of developing these derivatives as promising antitubercular, antibacterial and antifungal agents. 